Article

\title{
Application of a Low Cost Ceramic Filter for Recycling Sand Filter Backwash Water
}

\author{
Md Shafiquzzaman * (D), Abdullah Al-Mahmud, Saleem S. AlSaleem ${ }^{(D)}$ and Husnain Haider \\ Department of Civil Engineering, College of Engineering, Qassim University, Buraidah 52571, Saudi Arabia; \\ eng.almhmo0od@hotmail.com (A.A.-M.); alsaleem@qec.edu.sa (S.S.A.); husnain@qec.edu.sa (H.H.) \\ * Correspondence: shafiq@qec.edu.sa; Tel.: +966-580-811-458
}

Received: 17 December 2017; Accepted: 30 January 2018; Published: 3 February 2018

\begin{abstract}
The aim of this study is to examine the application of a low cost ceramic filter for the treatment of sand filter backwash water (SFBW). The treatment process is comprised of pre-coagulation of SFBW with aluminum sulfate (Alum) followed by continuous filtration usinga low cost ceramic filter at different trans-membrane pressures (TMPs). Jar test results showed that $20 \mathrm{mg} / \mathrm{L}$ of alum is the optimum dose for maximum removal of turbidity, Fe, and Mn from SFBW. The filter can be operated at a TMP between 0.6 and $3 \mathrm{kPa}$ as well as a corresponding flux of $480-2000 \mathrm{~L} / \mathrm{m}^{2} / \mathrm{d}$ without any flux declination. Significant removal, up to $99 \%$, was observed forturbidity, iron (Fe), and manganese (Mn). The flux started to decline at $4.5 \mathrm{kPa}$ TMP (corresponding flux $3280 \mathrm{~L} / \mathrm{m}^{2} / \mathrm{d}$ ), thus indicated fouling of the filter. The complete pore blocking model was found as the most appropriate model to explain the insight mechanism of flux decline. The optimum operating pressure and the permeate flux were found to be $3 \mathrm{kPa}$ and $2000 \mathrm{~L} / \mathrm{m}^{2} / \mathrm{d}$, respectively. Treated SFBW by a low cost ceramic filter was found to be suitable to recycle back to the water treatment plant. The ceramic filtration process would be a low cost and efficient option to recycle the SFBW.
\end{abstract}

Keywords: sand filter backwash water; coagulation and flocculation; ceramic filter; flux; TMP; Turbidity; Fe; Mn

\section{Introduction}

In current practice, ground water is being treated by conventional treatment processes including oxidation, coagulation, flocculation, sedimentation, and sand filtration. To maintain the efficient flux in filtration, it is essential to perform regular backwashing of the sand filter (one/twice a day). During this process, a large amount of wastewater is produced, particularly from the sand filter backwashing. It is estimated that, on average, approximately $2-10 \%$ of drinking water produced by conventional water treatment plant (WTP) is used for backwashing [1]. A backwash operation typically entails flushing the water in the reverse direction to that of normal flow. During the process, the accumulated contaminants are detached from the filter, and the resulting water is called sand filter backwash water (SFBW) that contains a high amount of suspended solid, colloidal materials, inorganic metals (Fe, Mn, and $\mathrm{Al}$ ), natural organic matter, bacteria, viruses, invertebrates, and protozoa.

In many parts of the world, water-treatment plants are using a sedimentation basin to recycle the backwash water to the treatment plant [2,3]. In the Kingdom of Saudi Arabia (KSA), it is estimated that approximately 26 million $\mathrm{m}^{3}$ /year of treated water is used during the backwashing processes of filtration plants. So far, most of WTPs in the KSA typically discharge their generated SFBW into evaporation ponds or municipal sewerage systems. The backwash water in the evaporation pond may cause contamination of groundwater through leaching of heavy metals from pond sediments. Additionally, growing urbanization and industrialization trends and limited groundwater resources are likely to lead to water scarcity in the KSA in the near future. As per recent legislation, municipalities 
in the KSA are required to improve their water conservation practices and reduce the cost of disposing backwash water by reducing its production. Thus, recycling the filter backwash water is of great interest, and instead of being disposed, the generated backwash water can be recycled back to the main plant by introducing a suitable treatment process.

Separation of solids and removal of inorganic metals such as Fe and $\mathrm{Mn}$ are required for reuse of SFBW. Membrane filtration is one of the most viable methods in treating SFBW. In recent years, several studies have been conducted on recycling the SFBW using potential methods such as ultra-filtration (UF) or microfiltration (MF) [3-8]. However, membrane fouling is one of the impediments as it can reduce the permeate flux and increase the frequency of membrane cleaning.

One of the key methods of reducing membrane fouling and improving the water quality is the pretreatment of SBFW by the coagulation and flocculation process [9-13]. Pretreatment is performed ahead of the membrane separation to enlarge the flocculants for fouling mitigation. Alum-based coagulants such as aluminum sulfate $\left(\mathrm{Al}_{2}\left(\mathrm{SO}_{4}\right)_{3}\right)$ are generally used as cost-effective coagulants in the coagulation and flocculation process. The consistency of the filtration flux largely depends on the size and structure of the flocculants formation, which eventually dependson the operating conditions such as $\mathrm{pH}$ and coagulant dosages [14-16]. For alum coagulation, size and structure of the flocculants are induced by various hydrolyzing Al species [17]. The application of an alum coagulant in a coagulation/microfiltration process has beeninvestigated in the recent past [18-20]. A previous study suggested that pre-coagulation of SFBW enhances the quantity and quality of filtrate water through enlarging submicron particles that eventually delay the clogging of membrane pores [20]. Therefore, pre-coagulation maybe one of the most suitable options for recycling theSFBW through membrane filtration.

Due to high initial cost and energy requirements, the application of MF or UF in treating SFBW is limited in most of the countries, including the KSA. Therefore, a low-cost and low-pressure ceramic filter, as a membrane process, is feasible for treating SFBW in this region. In our previous study, a low-cost and simple ceramic filter made with locally available cheap materials (clay soil and rice bran) was developed for the treatment of groundwater [21]. Eventually, the ceramic filter was applied to a membrane bioreactor (MBR) process for high-strength wastewater and greywater treatment $[22,23]$. This ceramic filter, with a pore size of 1-5 $\mu \mathrm{m}$, was found to be successful in separating activated sludge flocculants as a commercial polymeric membrane in wastewater treatment. Moreover, the low-pressure filter can be attributed to its low power consumption and low fouling.

The aim of the current study is to investigate the feasibility of using a simple ceramic-filter coupled with the coagulation and flocculation process to treat the SFBW and to produce high-quality recyclable water.

\section{Materials and Methods}

\subsection{Backwashed Water Samples}

SFBW samples were taken from the sand filter backwashed water drain of the Bruidah water treatment plant located in Buraidah city, KSA. Since turbidity as well as the compositions of Fe and Mn of the SFBW fluctuated during backwashing, all samples were collected with a 20 L Jar immediately after the start of sand filter backwash operation. Fresh backwash water samples were brought back to the laboratory and immediately analyzed or used for experiments without any pre-treatment.

\subsection{Low Cost Ceramic Filter}

A cylindrical shaped ceramic filter was made using locally available clay soil and rice bran in Bangladesh. The clay soil is also easily available in the KSA. However, saw dust can be used as a replacement of rice bran in the KSA. The manufacturing process of the ceramic filter used in this study was adapted from our previous study [21]. The clay soil sample was dried, ground with a hammer, and sieved through a $0.5-\mathrm{mm}$ sieve. The rice bran was dried and sieved through a $1 \mathrm{~mm}$ 
sieve. Sieved soil and rice bran were then mixed at a ratio of 80:20 (by weight) followed by making dough by adding water. The dough was then casted in a cylindrical-shaped mold to make the filter. The resulting ceramic filters were cylindrical in shape and hollow with one side open and had a height of $10 \mathrm{~cm}$ and a thickness of $2 \mathrm{~cm}$ (Figure 1a). Finally, the filter was sun dried for $48-72 \mathrm{~h}$ followed by firing in a muffle furnace in a small-scale pottery kiln at $900{ }^{\circ} \mathrm{C}$ for $4-5 \mathrm{~h}$ (Figure $1 \mathrm{~b}$ ). The pore size of the filter was measured to be 1-5 $\mu \mathrm{m}$. The pore size of the filter was estimated by comparing the particle size distribution of turbid water (water with clay mixture) before and after the filtration with the ceramic filter. Manufacturing cost was estimated to be \$0.2-0.3 US with an active filter area of $0.039 \mathrm{~m}^{2}$ per filter [21].

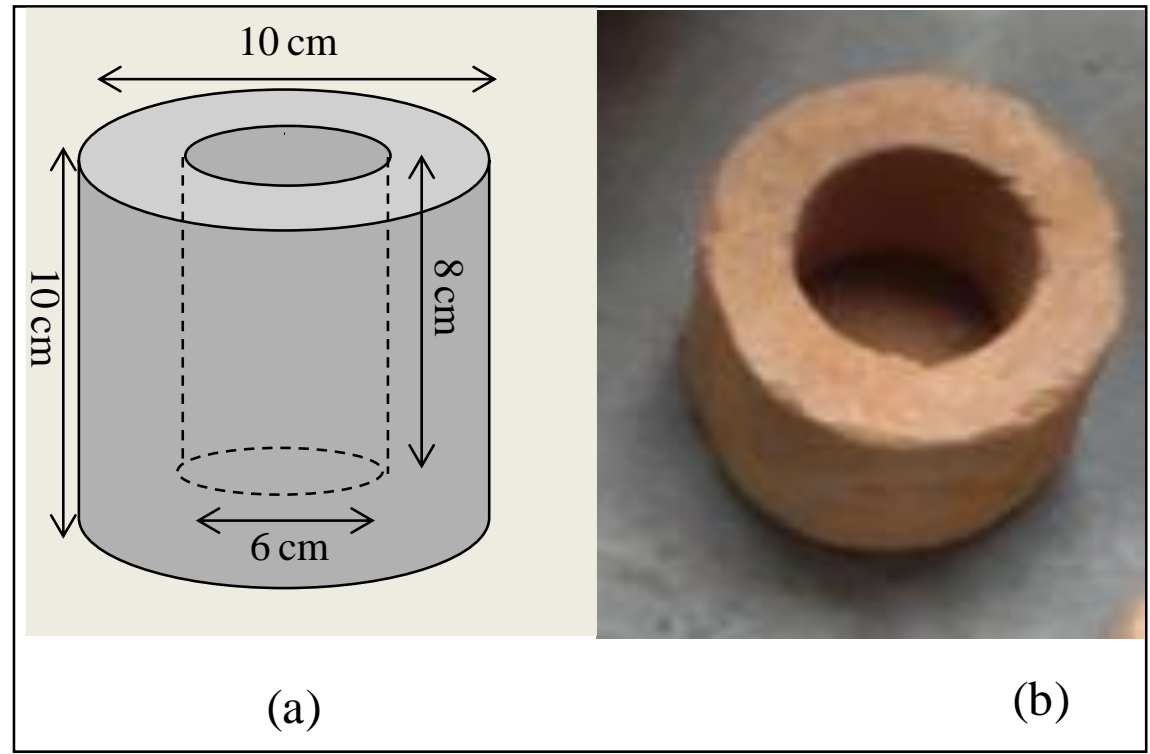

Figure 1. (a) Schematic presentation of ceramic filter; (b) Ceramic filter after burning.

\subsection{Water Quality Analysis}

Physical and chemical analysis of the water samples were conducted in the laboratory of Buraidah water treatment plant. Electrical conductivity (EC) and $\mathrm{pH}$ were measured with the help of an HMP6 $(\mathrm{HACH}$, Loveland, CO, USA), while turbidity was measured using the turbidity meter (2100Q, HACH, Loveland, CO, USA). Total dissolved solids (TDS) were measured by an Ultra-meter II 6P (Myron L, Carlsbad, CA, USA) by immersing the electrode in the sample. Alkalinity was measured using the standard titrationmethod. Total $\mathrm{Fe}$, total $\mathrm{Mn}$, phosphate $\left(\mathrm{PO}_{4}\right)$, silica $(\mathrm{Si})$, fluoride $(\mathrm{F})$, and sulfate $\left(\mathrm{SO}_{4}\right)$ were measured by Spectrophotometer (HACH DH-5000, HACH, Loveland, $\left.\mathrm{CO}, \mathrm{USA}\right)$ using relevant reagents provided by $\mathrm{HACH}$. Chloride $(\mathrm{Cl})$ was measured by titration with potassium chromate and silver nitrate solutions. All the standard reagent solutions were purchased from the Fouz Chemical Company, Dammam, KSA. Total hardness, calcium (Ca), and magnesium (Mg) were measured by retraction methods using HACH test kits. Suspended solids (SS) were measured as perthe standard methods.

\subsection{Alum as a Coagulant $\left(\mathrm{Al}_{2}\left(\mathrm{SO}_{4}\right)_{3}\right)$}

Powdered alum $\left(\mathrm{Al}_{2}\left(\mathrm{SO}_{4}\right)_{3} \cdot 12 \mathrm{H}_{2} \mathrm{O}\right)$ was purchased from a local laboratory in the city of Buraidah, KSA and used as the coagulant. Before each experiment, a fresh coagulant solution of $10 \mathrm{mg} / \mathrm{mL}$ concentration was prepared by mixing $10 \mathrm{~g}$ of Alum powder in $1 \mathrm{~L}$ of distilled water. 


\subsection{Coagulation and Flocculation Experiments}

A standard jar test wascarried out at $20{ }^{\circ} \mathrm{C}$ to performcoagulation and flocculation experiments. All the jar tests were conducted using a four stirrer A\&F jar test apparatus(JM4, Nvatech International). The jar test apparatus consists of four motors connected to four steel paddle stirrers with a speed control unit; the speed of the motors is adjustable to 200 RPM. Plastic beakers with $1000 \mathrm{~mL}$ SFBW were placed under the paddle stirrer and desired concentrations of alum solutions were then added to the beakers. All the jar tests were conducted by first rapidly mixing (coagulation at $100 \mathrm{RPM}$ ) for $2 \mathrm{~min}$, slowly mixing (flocculation at $40 \mathrm{RPM}$ ) for $20 \mathrm{~min}$, and then left to settle for $5 \mathrm{~min}$. The procedure was adapted from the previous study [24]. After allowing the coagulant to settle with contaminants for $5 \mathrm{~min}$, the suspension of the beaker was collected very carefully, and turbidity as well as Fe and $\mathrm{Mn}$ contents were measured. A total of eight jar tests with different doses of alum (5-100 mg/L) were carried out at neutral $\mathrm{pH}$ (7.2) to determine the optimum doses. Each jar test was carried out in triplicate to confirm reproducibility of the results.

\subsection{Filtration Experiments}

A lab-scale continuous filtration system coupled withcoagulation and flocculation processes was designed to investigate its potentiality to remove turbidity, Fe, and Mn. An optimal condition of the filtration system was identified based on the operational flux and the removal efficiency. Figure 2 presents a schematic view of the experimental setup. The filtration experiments were carried out in dead-end filtration mode. Two rectangular tanks made of a 12-mm thick thermoplastic glass were used as the coagulant tank and the filtration tank for each experimental stage. The dimension of each tank was $40 \mathrm{~cm}$ in length, $40 \mathrm{~cm}$ in width, and $60 \mathrm{~cm}$ in height. Inside the filtration tank, the ceramic filter was placed on the wooden boards to ensure the effective use of the entire filter's surface area for filtration. The filter was connected to the final water tank through a pressure gauge and a suction pump. An air diffuser was placed under the filter, and continuous air supply was provided to defend the accumulation of the solid on the filter surface. Prior to each experiment, raw SFBW was pre-coagulated using an optimum alum dose $(20 \mathrm{mg} / \mathrm{L})$ which was establishedthrough the coagulation and flocculation tests. Pre-coagulation was performed simultaneously with the coagulation and flocculation experiments, except for the $5 \mathrm{~min}$ settling step. The pre-coagulated SFBW was manually transferred to the coagulation tank on a regular basis. The effluent of the coagulation tank was then transferred to the filtration tank using the feed pump. The permeate effluent (final water) was obtained by the suction pump through the filter.

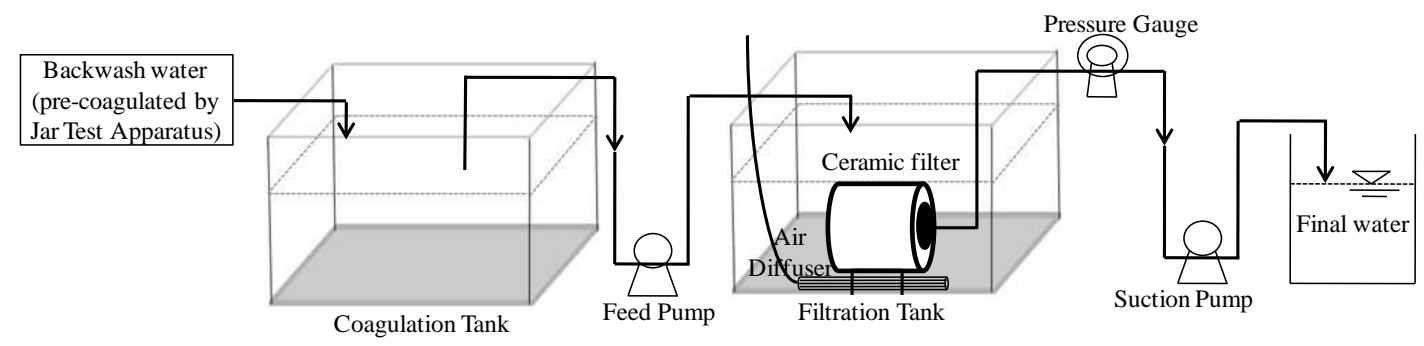

Figure 2. Schematic diagram of filtration experiments.

A total of four experimental runs were conducted with different fixed trans-membrane pressure (TMP) values as presented in Table 1 . All the filtration experiments were conducted at $20{ }^{\circ} \mathrm{C}$ temperature. The permeate flux $\left(\mathrm{L} / \mathrm{m}^{2} / \mathrm{d}\right)$ was determined by measuring the daily flow rate $(\mathrm{L} / \mathrm{d})$ and dividing it by the total active surface area $\left(\mathrm{m}^{2}\right)$ of the filter. Each experiment was operated continuously, and the daily flow rate was estimatedevery day by measuring the amount of filtered water in one minute by a stop watch and a measurement cylinder. Three water samples (raw SFBW, water from 
the coagulation tank, and permeate) were collected regularly to analyze turbidity as well as Fe and Mn concentrations.

Table 1. The detailed specifications of the filtration experiments. TMP = trans-membrane pressure.

\begin{tabular}{ccccc}
\hline Experimental Run & TMP (kPa) & Flux (L/m $\mathbf{2} / \mathbf{d})$ & $\begin{array}{c}\text { Experiment } \\
\text { Duration (Day) }\end{array}$ & $\begin{array}{c}\text { Alum Dose for } \\
\text { Pre-Coagulation (mg/L) }\end{array}$ \\
\hline Run-1 & 0.6 & 450 & $1-6$ & 20 \\
Run-2 & 1.5 & 1050 & $7-14$ & 20 \\
Run-3 & 3 & 2000 & $15-19$ & 20 \\
Run-4 & 4.5 & 3000 & $20-26$ & 20 \\
\hline
\end{tabular}

\subsection{Filter Fouling Mechanism}

For porous membranes, most fouling mechanisms are related to the active pore of the membrane and the processes by which a number of active pore reductions happen. Based on this, four basic types of fouling mechanisms, i.e., complete pore blocking, intermediate pore blocking, standard pore blocking, and cake-layer formation, can be identified (Figure 3). Complete pore blocking occurs when the particles are larger than the membrane pore and are deposited on the membrane surface, which blocks the entrance of the membrane pores completely with no overlapping particles. Intermediate pore blocking occurs when the particle size is similar than the membrane pore size. The intermediate blocking is less restrictive over complete blocking because it considers thatsome particles may settle over others. That means that not every particle blocksapore. Standard blocking occurs inside the membrane pores and is caused by the particles size being smaller than the membrane pore. Cake layer forms on the membrane surface through accumulation of particles that are larger than the membrane pore size. The cake layer grows with time and does not penetrate inside the pore.

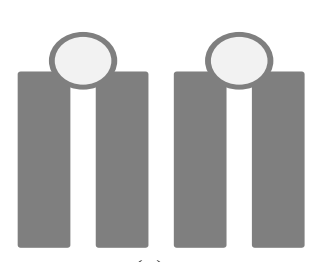

(a)

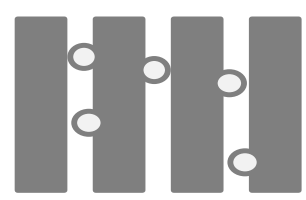

(c)

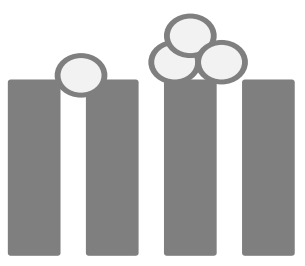

(b)

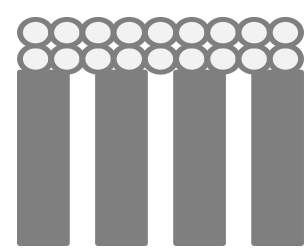

(d)

Figure 3. Schematic representation of different pore fouling mechanisms considered by the Hermia's model: (a) complete pore blocking; (b) intermediate pore blocking; (c) standard pore blocking, and (d) cake layer formation.

Based on constant pressure and dead-end filtration laws, empirical models (Equation (1)) were developed by Hermia [25] to describe the four types of basic fouling phenomena [26,27].

$$
\frac{d^{2} t}{d V^{2}}=k\left(\frac{d t}{d V}\right)^{n}
$$

where $t$ is filtration time, $V$ is the permeate volume, $k$ is constant, and $n$ is a constant that depends on the fouling mechanism. 
The linear expressions of Equation (1) are given in Table 2. In Table 2, the constants $k_{c b}, k_{i b}, k_{s b}$, and $k_{c l}$ are the system parameters relating to complete pore blocking, intermediate pore blocking, standard pore blocking, and cake-layer formation model, respectively. A plot of $\ln J$ vs. $t, 1 / J$ vs. $t$, $1 / J^{0.5}$ vs. $t$, and $1 / J^{2}$ vs. $t$ gives a straight line with a slope of $k_{c b}, k_{i b}, k_{s}$, as well as $k_{c l}$, and y-intercept of $\ln J_{0}, 1 / J_{0}, 1 / J_{0} 0.5$, and $1 / J_{0}^{2}$ for complete pore blocking, intermediate pore blocking, standard pore blocking, and cake-layer formation model, respectively. The appropriate applicability of these models can be confirmed by comparing the values of the coefficient of correlation $\left(\mathrm{R}^{2}\right)$ obtained from the linear regression analysis as well as an error analysis between experimental and calculated flux data.

Table 2. Equations in Hermia's model equations for four type of fouling mechanisms.

\begin{tabular}{clc}
\hline \multicolumn{1}{c}{ Fouling Mechanism } & \multicolumn{1}{c}{ Equations } & Constant \\
\hline Complete pore blocking $(\mathrm{n}=2)$ & $\begin{array}{l}\text { Basic equation: } J=J_{0} \exp \left(-k_{c b} t\right) \\
\text { Linear form: } \ln J=\ln J_{0}+k_{c b} t\end{array}$ & $k_{c b}$ \\
\hline Intermediate pore blocking $(\mathrm{n}=1)$ & $\begin{array}{l}\text { Basic equation: } J=\frac{J_{0}}{\left(1+K_{i b} A J_{0} t\right)} \\
\text { Linear form: } \frac{1}{J}=\frac{1}{J_{0}}+k_{i b} t\end{array}$ & $k_{i b} A$ \\
\hline \multirow{2}{*}{ Standard pore blocking $(\mathrm{n}=1.5)$} & Basic equation: $J=\frac{J_{0}}{\left(1+0.5 K_{s b}\left(A J_{0}\right)^{1 / 2} t\right)^{2}}$ & \\
\hline Cake layer formation $(\mathrm{n}=0.5)$ & Basic equation: $J=\frac{1}{J_{s b} A^{1 / 2}}$ & \\
\hline & Linear form: $\frac{1}{J^{2}}=\frac{1}{J_{0}^{2}}+k_{c l} t$ & $k_{c b}=2 K_{c b} A^{2}$ \\
\hline
\end{tabular}

\section{Results and Discussions}

\subsection{SFBW Quality of the Buraidah Water Treatment Plant}

Backwash water from the sand filter of the Buraidah water treatment plant was collected and analyzed for physical and chemical quality. A total of 13 samples were collected at different times and analyzed in the laboratory. Table 3 presents the minimum, maximum, and average value of raw SFBW water quality. As presented in Table 3, the $\mathrm{pH}$ value was found to be neutral with an average value of 7.2. Turbidity in the samples ranged between 1250 NTU and 304 NTU with an average value of 516 NTU. The amount of TDS ranged from 763 to $797 \mathrm{mg} / \mathrm{L}$, with an average of $773 \mathrm{mg} / \mathrm{L}$. A relatively high value of hardness that ranged from 297 to $308 \mathrm{mg} / \mathrm{L}$, with an average of $303 \mathrm{mg} / \mathrm{L}$, was measured. Consequently, as expected, the concentrations of Ca and Mg were also high, with average values of 82 and $23 \mathrm{mg} / \mathrm{L}$, respectively. Fe concentration ranged from 24 to $90 \mathrm{mg} / \mathrm{L}$, with an average value of $60 \mathrm{mg} / \mathrm{L}$. Manganese concentration ranged from 2.4-11 mg/L, with an average of $5.5 \mathrm{mg} / \mathrm{L}$. A high concentration of silica was also measured in backwash water with an average value of $18 \mathrm{mg} / \mathrm{L}$. Total suspended solids ranged from 145-190 mg/L, with an average of $165 \mathrm{mg} / \mathrm{L}$. The $\mathrm{pH}$ value was also acceptable, and no further treatment was required. Total hardness was also found to be acceptable and within the limit of the World Health Organization (WHO) guideline for drinking water [28]. Analysis of SFBW revealed that the average concentrations of turbidity (516 NTU), Fe (60 mg/L), and Mn (5.5 mg/L) were significantly higher than the WHO standard values [28]. Accordingly, this study focused on the removal of turbidity, Fe, and Mn from SFBW to make it suitable for recycling purpose. 
Table 3. Sand filter backwash water (SFBW) quality of the Buraidah water treatment plant.

\begin{tabular}{|c|c|c|c|c|}
\hline Parameter & Unit & $\operatorname{Min}(n=13)$ & Average $(n=13)$ & $\operatorname{Max}(n=13)$ \\
\hline $\mathrm{pH}$ & - & 7.1 & 7.2 & 7.7 \\
\hline Turbidity & NTU & 304 & 516 & 1250 \\
\hline Total dissolved solids (TDS) & $\mathrm{mg} / \mathrm{L}$ & 763 & 773 & 797 \\
\hline Conductivity & $\mu \mathrm{s} / \mathrm{cm}$ & 1533 & 1551 & 1598 \\
\hline Total Hardness & $\mathrm{mg} / \mathrm{L}$ & 297 & 303 & 308 \\
\hline Calcium & $\mathrm{mg} / \mathrm{L}$ & 80 & 83 & 85 \\
\hline Magnesium & $\mathrm{mg} / \mathrm{L}$ & 22 & 23 & 24 \\
\hline Alkalinity & $\mathrm{mg} / \mathrm{L}$ & 124 & 132 & 134 \\
\hline Manganese & $\mathrm{mg} / \mathrm{L}$ & 2.4 & 5.5 & 11 \\
\hline (Fe) Iron & $\mathrm{mg} / \mathrm{L}$ & 24 & 60 & 90 \\
\hline Fluorides & $\mathrm{mg} / \mathrm{L}$ & 0.0 & 0.3 & 0.4 \\
\hline Chlorides & $\mathrm{mg} / \mathrm{L}$ & 319 & 326 & 331 \\
\hline Sulfates & $\mathrm{mg} / \mathrm{L}$ & 100 & 144 & 170 \\
\hline Silica & $\mathrm{mg} / \mathrm{L}$ & 16 & 18 & 22 \\
\hline Total suspended solids (TSS) & $\mathrm{mg} / \mathrm{L}$ & 145 & 165 & 190 \\
\hline
\end{tabular}

\subsection{Coagulation and Flocculation of SFBW by Alum}

Turbidity, Fe, and Mn removal form SFBW at various dosages of alum are presented in Figure 4. As illustrated in Figure 4, an average turbidity removal of around 14\% (1250 NTU in raw water) was achieved at a $5 \mathrm{mg} / \mathrm{L}$ dose of alum. The average removal percentage increased up to $70 \%$ with increases in the alum dose up to $20 \mathrm{mg} / \mathrm{L}$. No further increase in removal efficiency was observed at the alum dosesof 30, 40, 50, and $100 \mathrm{mg} / \mathrm{L}$. Similarly, an average Fe removal of $13.2 \%(102.5 \mathrm{mg} / \mathrm{L}$ in raw water) was achieved at a $5 \mathrm{mg} / \mathrm{L}$ alum dose. The removal efficiency increased with the increase in the alum dose up to $20 \mathrm{mg} / \mathrm{L}$. The removal efficiency increased to $29 \%$ at a $10 \mathrm{mg} / \mathrm{L}$ alum dose, further increased to $56.7 \%$ at a $15 \mathrm{mg} / \mathrm{L}$ alum dose, and reached its maximum (70\%) at a $20 \mathrm{mg} / \mathrm{L}$ alum dose. The average removal efficiency remained steady with further increases in alum doses of $30,40,50$, and $100 \mathrm{mg} / \mathrm{L}$. Average Mn removal of 39.9\% (12.7 mg/L in raw water) was obtained at a $5 \mathrm{mg} / \mathrm{L}$ alum dose. The removal efficiency increased with the increase in alum doses up to $20 \mathrm{mg} / \mathrm{L}$. The removal efficiency increased to $46.8 \%$ at a $10 \mathrm{mg} / \mathrm{L}$ alum dose, further increased to $68.4 \%$ at a $15 \mathrm{mg} / \mathrm{L}$ alum dose, and reached its maximum (74.9\%) at a $20 \mathrm{mg} / \mathrm{L}$ alum dose. The average removal efficiency was almost steady for further increases of the alum dose to 30, 40, 50, and $100 \mathrm{mg} / \mathrm{L}$.

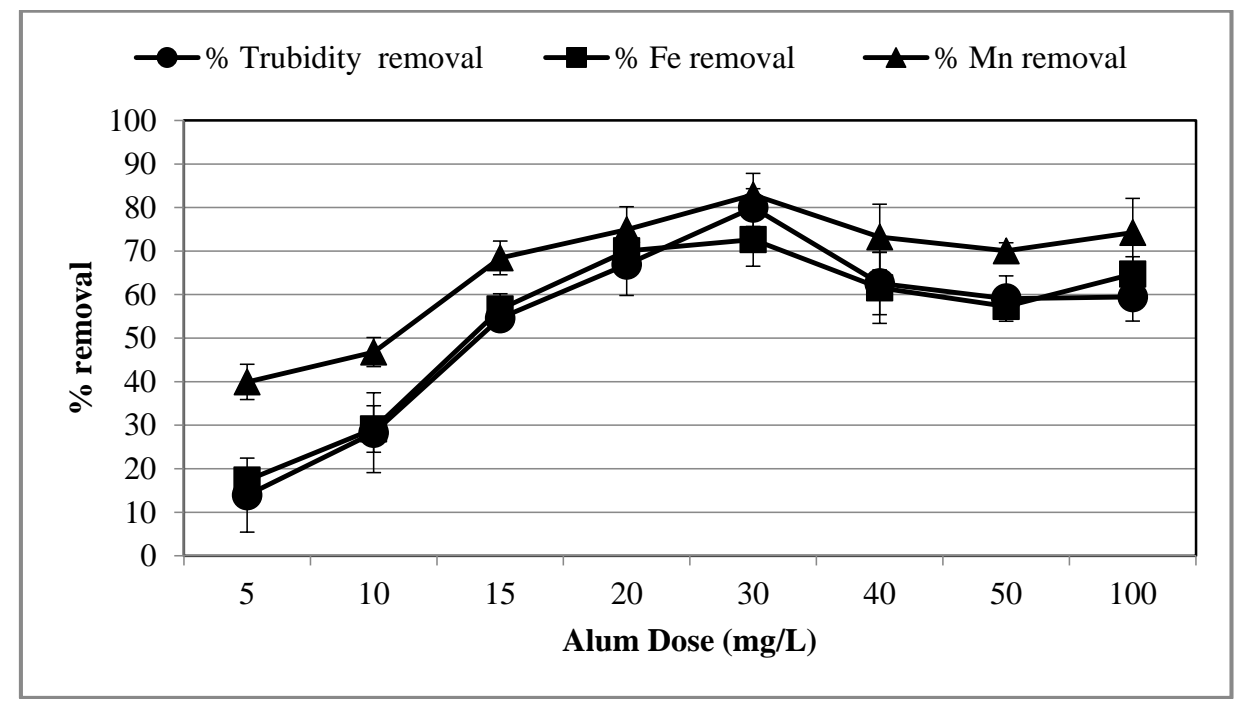

Figure 4. Variation of percent removal of turbidity, total Fe, and total Mn with alum doses. Raw water: turbidity $=1250 \mathrm{NTU}$, total $\mathrm{Fe}=102 \mathrm{mg} / \mathrm{L}$, and total $\mathrm{Mn}=12.7 \mathrm{mg} / \mathrm{L}$. Error bar shows the standard deviation of triplicate experiments. 
From the results of coagulation and flocculation experiments, it was primarily observed that $20 \mathrm{mg} / \mathrm{L}$ or higher doses of alum are necessary for achieving the maximum removal of turbidity, $\mathrm{Fe}$, and Mn from SFBW. $t$-test was conducted using the analytical tools in Microsoft Excel to establish the difference between the removal at a $20 \mathrm{mg} / \mathrm{L}$ alum dose and removals at the other alumdoses. The difference is considered to be statistically significant when the $p$-value is $<0.05$. When the $p$ value is $>0.05$, the difference of removal is not considered to be significant. For turbidity removal, $p$-values of $0.00004,0.0006,0.018$, and 0.04 correspond to 5, 10, 15, and $50 \mathrm{mg} / \mathrm{L}$ alum doses, respectively, and indicate significant difference in turbidity removal atthe $20 \mathrm{mg} / \mathrm{L}$ dose and at the $5,10,15$, and $50 \mathrm{mg} / \mathrm{L}$ doses. High $p$-values of $0.72,0.28$, and 0.09 for 30, 40, and $100 \mathrm{mg} / \mathrm{L}$, respectively, indicateno significant removal at these doses.

For Fe removal, $p$-values of $0.001,0.003$, and 0.03 correspond to 5, 10, and $15 \mathrm{mg} / \mathrm{L}$ alum doses, respectively, and indicate significant differences between Fe removal by $20 \mathrm{mg} / \mathrm{L}$ dose and those by 5,10 , and $15 \mathrm{mg} / \mathrm{L}$ doses. For 30, 40, 50, and $100 \mathrm{mg} / \mathrm{L}$ doses, the $p$-values of $0.45,0.19,0.06$, and 0.36 , respectively, show insignificant differences in removal efficiencies at these doses. For $\mathrm{Mn}$ removal, the $p$-values of 0.0008 and 0.0146 correspond to 5 and $10 \mathrm{mg} / \mathrm{L}$ alum doses, respectively, and indicate a significant difference in turbidity removal by the $20 \mathrm{mg} / \mathrm{L}$ dose and those by 5 and $10 \mathrm{mg} / \mathrm{L}$ doses. For 15, 30, 40, 50, and $100 \mathrm{mg} / \mathrm{L}$ doses, $p$-values were found to be $0.16,0.63,0.34,0.20$, and 0.91 , respectively, which indicates insignificant variations in removal efficiencies with increased doses. Overall results suggest that significantly higher removals of turbidity, $\mathrm{Fe}$, and $\mathrm{Mn}$ were achieved primarily at a minimum of a $20 \mathrm{mg} / \mathrm{L}$ alum dose. Therefore, the $20 \mathrm{mg} / \mathrm{L}$ alum dose was found to be optimum and recommended for further continuous experiments.

\subsection{Lab Scale Filtration Experiments}

\subsubsection{FluxProfile with Different TMPs}

The laboratory-scale continuous-ceramic filtration experiments coupled with coagulation (Run-1 to Run-4) were conducted continuously for 26 days by varying TMP (Table 1). SFBW was pre-coagulated with a $20 \mathrm{mg} / \mathrm{L}$ alum doseona daily basis for each run. The variations of fluxes with TMPs during Run-1 to Run-4 are presented in Figure 5a. Prior to each run, the filter was cleaned with a soft brush and washed with tap water to remove fouled materials accumulated on the filter. Therefore, initial conditions for all runs are considered to be the same. Run-1 was carried out continuously for 7 days with a fixed pressure of $0.6 \mathrm{kPa}$. Corresponding flux at this pressure was measured around $450 \mathrm{~L} / \mathrm{m}^{2} / \mathrm{d}$. It was observed that the flux remained almost constant as the days progressed until day 7. After 7 days, the TMP (Run-2) was increased to $1.5 \mathrm{kPa}$ and the experiment was carried out continuously until day 14 (8 days). The initial flux at this pressure was measured to be approximately $1000 \mathrm{~L} / \mathrm{m}^{2} / \mathrm{d}$ and remained constant until day 14. In Run-3, the TMP was further increased to $3.0 \mathrm{kPa}$ and operated continuously for 5 days (days 15-19). The initial flux at this pressure was measured around $2000 \mathrm{~L} / \mathrm{m}^{2} / \mathrm{d}$, which remained constant until day 19. The TMP in Run-4 was further increased to $4.5 \mathrm{kPa}$, and filtration was carried out continuously for 7 days (days 20-26). The initial flux at this pressure was measured to be approximately $3000 \mathrm{~L} / \mathrm{m}^{2} / \mathrm{d}$ at day 20 and slightly increased to 3280 and $3200 \mathrm{~L} / \mathrm{m}^{2} / \mathrm{d}$ on days 22 and 23 , respectively. On day 24 , the flux rapidly decreased to $2400 \mathrm{~L} / \mathrm{m}^{2} / \mathrm{d}$ and then continuouslydecreased as the day progressed. The flux was reduced to $1100 \mathrm{~L} / \mathrm{m}^{2} / \mathrm{d}$ on day 27 , thus indicating fouling of the filter that needed to be backwashed or cleaned at this stage. The fouling mechanism of the ceramic filter at a TMP of $4.5 \mathrm{kPa}$ was further analyzed using a different pore blocking model in Section 3.3.4. 

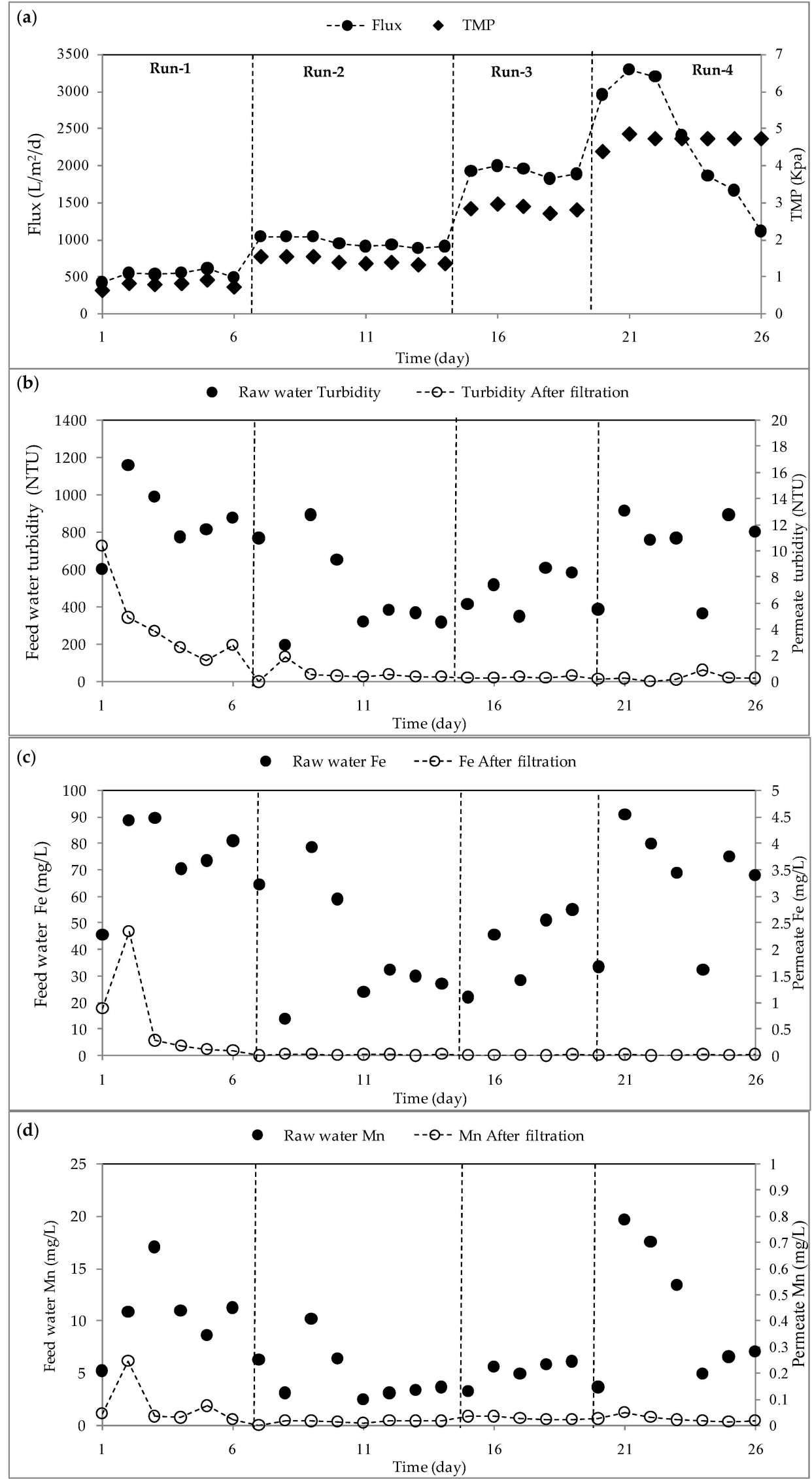

Figure 5. Continuous filtration experiments of 4 runs at different TMP: (a) variation of flux with TMP; (b) Turbidity in feed water and in thepermeate; (c) Fe in feed water and in the permeate, and (d) Mn in feed water and in the permeate. 


\subsubsection{Removal of Turbidity, Fe, and Mn}

Removal performance of turbidity, $\mathrm{Fe}$, and Mn of Run-1 through Run-4 are presented in Figure 5b-d respectively. In Run-1, feed water turbidity, Fe, and Mn were measured as 319-1160 NTU, $45-89.5 \mathrm{mg} / \mathrm{L}$, and $5.15-17 \mathrm{mg} / \mathrm{L}$, respectively. The concentrations in permeate were reduced to $<5 \mathrm{NTU}$ (except day 1), $<0.3 \mathrm{mg} / \mathrm{L}$ (except day 2 and 3), and $<0.1 \mathrm{mg} / \mathrm{L}$ (except day 2), respectively, which were approximately $99.4 \%$ of the average removal from the raw SFBW. In Run-2, feed water turbidity, Fe, and Mn were measured as 319-770 NTU, 14-78.5 mg/L, and 2.4-10.15 mg/L, respectively. After filtration, concentrations of turbidity, Fe, and Mn were reduced to $<2 \mathrm{NTU},<0.1 \mathrm{mg} / \mathrm{L}$, and $<0.05 \mathrm{mg} / \mathrm{L}$, respectively, which was equivalent to an average of $99 \%$ removal from the raw SFBW. In Run-3, feed water turbidity, Fe, and Mn were measured as 350-610 NTU, 22-55 mg/L, and 3.2-6.1 mg/L, respectively. The concentrations were reduced to $<0.5 \mathrm{NTU},<0.05 \mathrm{mg} / \mathrm{L}$, and $<0.05 \mathrm{mg} / \mathrm{L}$, respectively, at the permeate water, which was approximately $99.97 \%$ of the average removal from the raw SFBW. In Run-4, feed water turbidity, Fe, and Mn were measured as 365-915 NTU, 32.5-91 mg/L, and 3.6-19.6 mg/L, respectively. The concentrations were reduced to $<1 \mathrm{NTU},<0.03 \mathrm{mg} / \mathrm{L}$, and $<0.05 \mathrm{mg} / \mathrm{L}$, respectively, at the final water, which was approximately $99 \%$ of the average removal from the raw SFBW. Results demonstrated that the concentrations of turbidity, $\mathrm{Fe}$, and $\mathrm{Mn}$ in the final water (permeate) of all runs were acceptable and less than the WHO standard guideline [28]. Thus, the low cost ceramic filtration coupled with a coagulation process is proved to be a highly efficient method for the treatment of SFBW.

\subsubsection{OptimumFiltration Conditions}

Based on the significant influence of TMP, it is important to operate the submerged filter at an optimum pressure to minimize membrane fouling. In addition, optimum removal efficiency of contaminants at the optimum pressure is another key factor to be considered in the design of the filtration system. In the present study, concentrations of turbidity, $\mathrm{Fe}$, and $\mathrm{Mn}$ in permeates after filtration for all runs were below the standard limit of the WHO guideline fordrinking water, indicating that the permeate quality was not affected by the operating TMP. Therefore, the optimum operating condition would be calculated based on the flux decline at different TMP values. The following equation (Equation (2)) can be used to describe the relation between the flux and TMP in membrane filtration:

$$
J=\frac{\Delta P}{\mu\left(R_{m}+R_{f}\right)}
$$

where $J$ is the permeate flux, $\Delta P$ is TMP, $\mu$ is viscosity, $R_{m}$ is intrinsic membrane resistance, and $R_{f}$ is resistance due to the fouling effect.

In this research, the intrinsic membrane resistance and theviscosity of SFBW are assumed to be constant. Since the $\Delta P$ and the $R_{f}$ are the only variables in the filtration, there will be no decrease in the flux with time if there is no or negligible membrane fouling. Conversely, the decrease in flux implies that the cake layer or pore blocking by deposited particles caused significant resistance to permeate flow (the fouling effect). Therefore, the experimental results of the current study suggest that ceramic filtration can be operated at the optimum pressure of $3.0 \mathrm{kPa}$ (corresponding to a flux of $2000 \mathrm{~L} / \mathrm{m}^{2} / \mathrm{d}$ ) with modest fouling effect.

\subsubsection{Analysis of Fouling Mechanism of Ceramic Filter}

Despite the negligible fouling of the ceramic filter that occurred at low TMPs $(0.61-3.0 \mathrm{kPa})$, decline in the flux at a higher TMP ( $4.5 \mathrm{kPa})$ confirmed the fouling of the filter. In the present study, Hermia's models [25] were used to interpret the fouling phenomenon that occurs in the continuous filtration experiments in Run-4. Fitting the models with the experimental data indicates whether cake-layer formation (or pore blocking) controlled the flux decline or filter clogging in the filtration 
system. Figure 6a-d illustrate the different models' fitting of the experimental data obtained from the continuous filtration in Run-4.

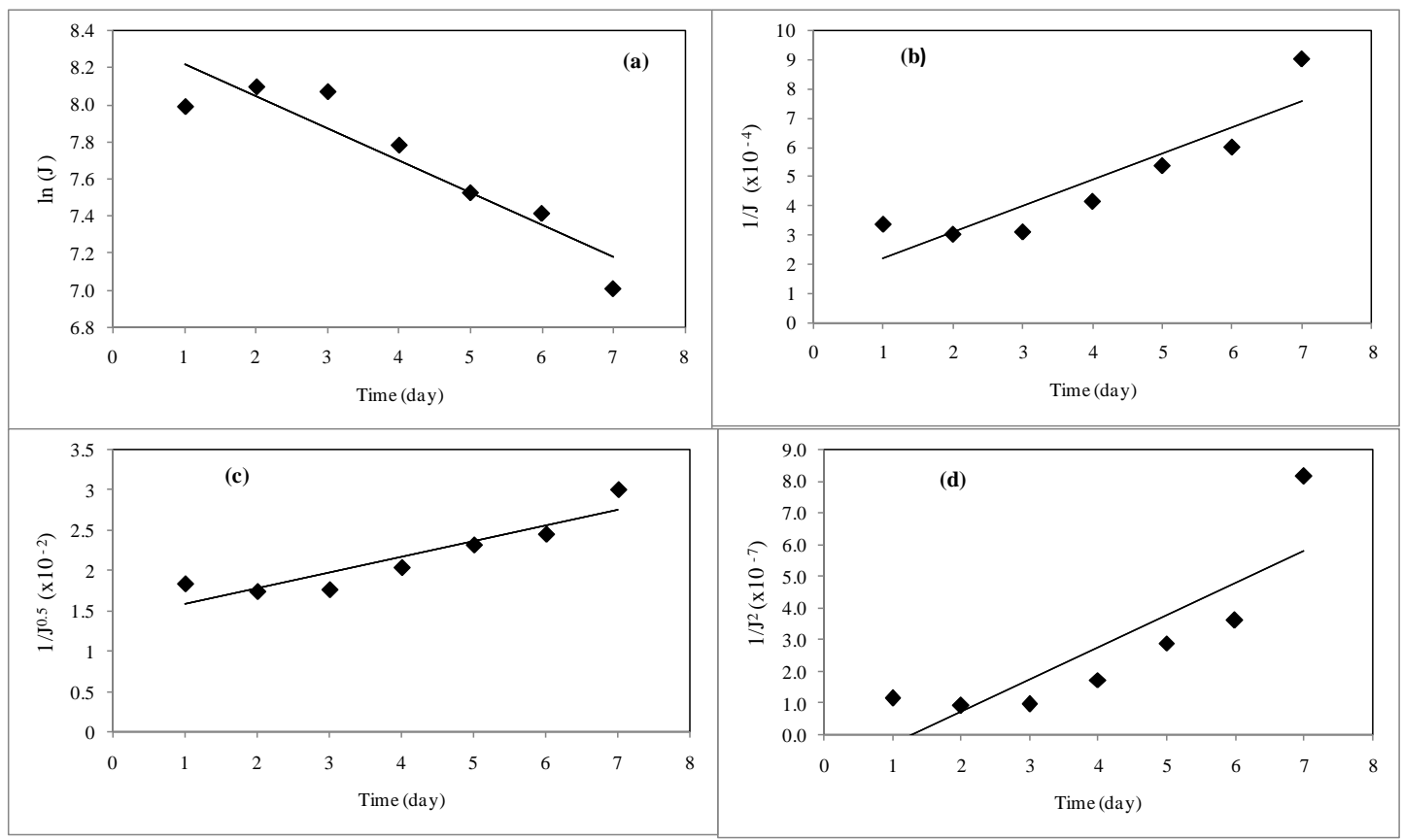

Figure 6. Linear plot of flux vs. time for different pore blocking models at $4.5 \mathrm{kPa}$ : (a) complete pore blocking model $(\ln (J)$ vs. $t)$; (b) intermediate pore blocking model $(1 / J$ vs. $t)$; (c) standard pore blocking model $\left(1 / J^{0.5}\right.$ vs. $\left.t\right)$, and $(\mathbf{d})$ cake layer formation model $\left(1 / J^{2}\right.$ vs. $\left.t\right)$ as given in.

The parameters of the linear regression analysis of each model are given in Table 4. From the table, it was observed that the intercept $\left(1 / J_{0}{ }^{2}\right)$ for the cake-layer model gives a negative value of the initial flux. Therefore, this model is not appropriate and cannot be applied for the interpretation of the flux decline mechanism and should be ignored for the further analysis of flux declination.

Table 4. Hermia's model parameters obtained from the linear regression analysis for the ceramic filter.

\begin{tabular}{cccccccc}
\hline \multicolumn{2}{c}{ Complete Pore Blocking } & \multicolumn{2}{c}{ Intermediate Pore Blocking } & \multicolumn{2}{c}{ Standard Pore Blocking } & \multicolumn{2}{c}{ Cake Layer Formation } \\
\hline$k_{c b}$ & $-1.7 \times 10^{-1}$ & $k_{i b}$ & $9.0 \times 10^{-5}$ & $K_{s b}$ & $2.0 \times 10^{-3}$ & $K_{c l}$ & $1.0 \times 10^{-7}$ \\
$\mathrm{R}^{2}$ & 0.86 & $\mathrm{R}^{2}$ & 0.81 & $\mathrm{R}^{2}$ & 0.84 & $\mathrm{R}^{2}$ & 0.73 \\
$\ln \left(J_{0}\right)$ & 8.4 & $1 / J_{0}$ & $1.3 \times 10^{-4}$ & $1 / J_{0} 0.5$ & $1.4 \times 10^{-2}$ & $1 / J_{0}{ }^{2}$ & $-1.3 \times 10^{-7}$ \\
$J_{0}$ & 4413 & $J_{0}$ & 7768 & $J_{0}$ & 5201 & $J_{0}$ & - \\
\hline
\end{tabular}

Based on the linear plots of other pore-blocking models and the correlation coefficients $\mathrm{R}^{2}$ shown in Figure 6a-c, it can be observed that the complete pore-blocking model (Figure 6a and Table 4) has the best linear fitting with the highest $R^{2}$ value of 0.86 . It can also be observed from Table 4 that the $R^{2}$ values of the intermediate and standard pore-blocking models are also reasonable, i.e., 0.81 and 0.84 , respectively. However, analysis of the percentage error of the experimental flux and the calculated flux shows that the complete pore-blocking model gives the lowest error (5-25\%) compared to the other two models (7-60\%). Therefore, the complete pore-blocking model most appropriately describes the mechanism of flux decline in the present study. Huang et al. [16] studied various resistances to filtration in a coagulation/filtration process. They observed that cake resistance (due to filtration cake formation) plays an important role in membrane filtration if coupled with coagulation, and pore blocking is negligible as the majority of particles are larger than a nominal size of membrane. However, in this study, a continuous air flow was provided on the surface of the filter, which would prevent the 
formation of any cake layer on the surface of the filter. Therefore, the fouling mechanism in the current study differed from the previous study.

\subsubsection{Filter Cleaning}

A simple washing technique using a soft brush was applied to the ceramic filter clogged in Run-4. The filter was gently brushed with the soft nylon brush then rinsed with tap water. The filtration flux was measured at the same pressure as that in Run-4 (4.5 kPa) using pure water after washing the filter. The recovery of the filtration flux is presented in Figure 7. More than $85 \%$ flux recovery was achieved without the conventional chemical cleaning procedure. Thus, the low-cost ceramic filter used in the current study would reduce the backwash operational cost of the filtration system.

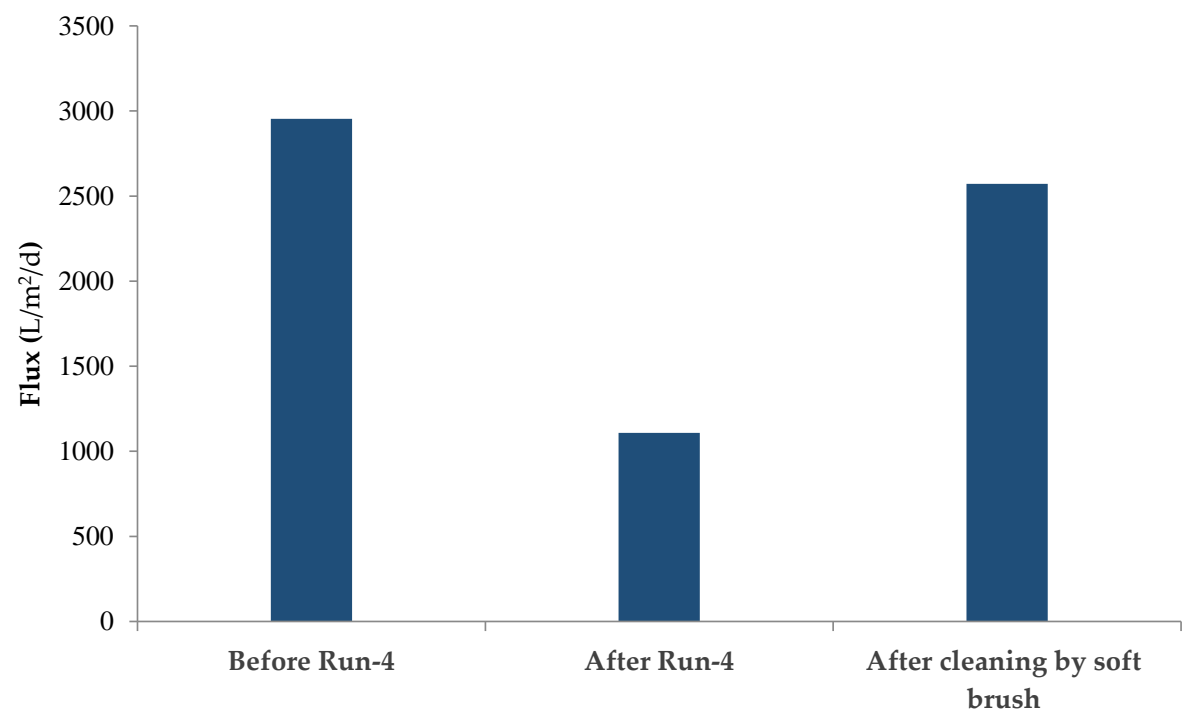

Figure 7. Recovery of pure water filtration flux by simple washing using soft brush in Run- 4 at $4.5 \mathrm{kPa}$.

\subsubsection{Filtered Water Characteristics and Recycle Options of SFBW}

The quality of the water obtained from the filtration system under the established optimal condition is presented in Table 5. Turbidity, Fe, and Mn removal were highly effective at the optimal flux conditions. The ceramic filter removed almost $99.9 \%$ of the turbidity, $\mathrm{Fe}$, and $\mathrm{Mn}$ from the raw SFBW. The total suspended solid (TSS) was reduced to $0 \mathrm{mg} / \mathrm{L}$ from $1650 \mathrm{mg} / \mathrm{L}$. The $\mathrm{pH}$ value of the filtered water did not change and was the same as that of the raw SFBW (7.2). The TDS concentration was $783 \mathrm{mg} / \mathrm{L}$ and not removed by the ceramic filter (raw water TDS $=773 \mathrm{mg} / \mathrm{L}$ ). Hardness, calcium, magnesium, alkalinity, chloride, and silica were also not removed by the ceramic filter. Concentrations of calcium $(99 \mathrm{mg} / \mathrm{L})$ and chloride $(335 \mathrm{mg} / \mathrm{L})$ in final water were found to be higher than the WHO standard limit. Fluoride was effectively reduced from $0.3 \mathrm{mg} / \mathrm{L}$ to $0.03 \mathrm{mg} / \mathrm{L}$ (i.e., $90 \%$ removal).

Table 5. Comparison of filtered water characteristics with World Health Organization (WHO) standard limit for drinking.

\begin{tabular}{cccccc}
\hline Parameter & Unit & Raw SFBW & $\begin{array}{c}\text { Permeate (after } \\
\text { Filtration) }\end{array}$ & $\begin{array}{c}\text { WHO Standard Limit } \\
\text { for Drinking Water }\end{array}$ & $\begin{array}{c}\text { Satisfy the WHO } \\
\text { Standard? }\end{array}$ \\
\hline $\mathrm{pH}$ & & 7.2 & 7.2 & $6.5-8.5$ & Yes \\
Turbidity & $\mathrm{NTU}$ & 516 & 0.4 & $0.1-5$ & Yes \\
TDS & $\mathrm{mg} / \mathrm{L}$ & 773 & 783 & $600-1000$ & Yes \\
Conductivity & $\mathrm{\mu s} / \mathrm{cm}$ & 1551 & 1567 & 2000 & Yes \\
Hardness & $\mathrm{mg} / \mathrm{L}$ & 303 & 312 & 500 & Yes \\
Calcium & $\mathrm{mg} / \mathrm{L}$ & 83 & 99 & $40-80$ & Yes \\
Magnesium & $\mathrm{mg} / \mathrm{L}$ & 23 & 15 & $20-30$ & Yes \\
Alkalinity & $\mathrm{mg} / \mathrm{L}$ & 132 & 138 & 600 & Yes \\
\hline
\end{tabular}


Table 5. Cont.

\begin{tabular}{cccccc}
\hline Parameter & Unit & Raw SFBW & $\begin{array}{c}\text { Permeate (after } \\
\text { Filtration) }\end{array}$ & $\begin{array}{c}\text { WHO Standard Limit } \\
\text { for Drinking Water }\end{array}$ & $\begin{array}{c}\text { Satisfy the WHO } \\
\text { Standard? }\end{array}$ \\
\hline Manganese & $\mathrm{mg} / \mathrm{L}$ & 5.5 & 0.02 & 0.1 & Yes \\
(Fe) Iron & $\mathrm{mg} / \mathrm{L}$ & 60 & 0.01 & 0.3 & Yes \\
Fluorides & $\mathrm{mg} / \mathrm{L}$ & 0.3 & 0.03 & 1.5 & Yes \\
Chlorides & $\mathrm{mg} / \mathrm{L}$ & 326 & 335 & 200 & Yes \\
Sulfates & $\mathrm{mg} / \mathrm{L}$ & 144 & 94 & $150-400$ & Yes \\
Silica & $\mathrm{mg} / \mathrm{L}$ & 18 & 16 & 0 & Yes \\
TSS & $\mathrm{mg} / \mathrm{L}$ & 165 & 0 & 0 & No \\
Total Coliform & $\mathrm{MPN} / \mathrm{ml}$ & $\mathrm{nm}$ & $\mathrm{nm}$ & 0 & No \\
Fecal Coliform & $\mathrm{MPN} / \mathrm{ml}$ & $\mathrm{nm}$ & $\mathrm{nm}$ & 0 & No \\
E-coli & $\mathrm{MPN} / \mathrm{ml}$ & $\mathrm{nm}$ & $\mathrm{nm}$ & & \\
\hline
\end{tabular}

$\mathrm{nm}=$ Not measured

In the present study, the analysis of microbiological parameters (coli-forms and E. coli) was not performed as the previous study showed that the ceramic filter of this study is comparatively weak in terms of removal of coli forms and E. coli [21]. Therefore, after a disinfection process, it is recommended that the SFBW treated by low a cost ceramic filter be recycled back to the water treatment plant. The treated SFBW can also be sent to the reverse osmosis (RO) process for further advanced treatment to reduce the TDS and hardness (Calcium and Magnesium).

\section{Conclusions}

Very high and unappreciable values of turbidity (516 NTU), Fe (62 mg/L), and Mn (5.5 mg/L) were found in the SFBW at a groundwater treatment plant in Buraydah, Qassim, KSA. A low cost ceramic filter is evaluated for its suitability to treat the SFBW to make it suitable for recycling.

In the coagulation and flocculation tests, average percentages (\%) of turbidity, $\mathrm{Fe}$, and $\mathrm{Mn}$ removals increased with increasing alum dose from 5 up to $20 \mathrm{mg} / \mathrm{L}$. Further increases in the alum dose to 30, 40,50 , and $100 \mathrm{mg} / \mathrm{L}$ did not significantly affect the removal efficiency $(p<0.05)$. Therefore, a $20 \mathrm{mg} / \mathrm{L}$ alum dose has been found as the optimum dose. In the filtration experiments, flux declination was not observed at a TMP between 0.6 to $3.0 \mathrm{kPa}$ until 19 days of continuous filtration.

Average concentrations of turbidity, $\mathrm{Fe}$, and $\mathrm{Mn}$ at the filter permeate were measured to be $<0.5 \mathrm{NTU},<0.05 \mathrm{mg} / \mathrm{L}$, and $<0.05 \mathrm{mg} / \mathrm{L}$, respectively, which are approximately $99 \%$ of the average removal from the raw SFBW. At $4.5 \mathrm{kPa}$ TMP, the flux was decreasedfrom 3000 to $1100 \mathrm{~L} / \mathrm{m}^{2} / \mathrm{d}$ on day-27, thus indicating fouling of the filter. Based on linear plots for four different fouling models, it was observed that the complete pore-blocking model gave the best linear fitting with the highest $\mathrm{R}^{2}$ value of 0.86 . Therefore, complete pore blocking occurred at $4.5 \mathrm{kPa}$ and the flux consequently declined. The optimum operating pressure and permeate flux were found to be $3 \mathrm{kPa}$ and $2000 \mathrm{~L} / \mathrm{m}^{2} / \mathrm{d}$, respectively.

It is recommended that SFBW treated by low a cost ceramic filter be recycled back to the water treatment plant after a disinfection process. The low-cost ceramic filter coupled with the coagulation and flocculation process is likely to have low-cost, low-energy consumption, and be a highly efficient option for recycling SFBW. The analysis of performance indicates that a low-cost ceramic filter could be employed successfully in large-scale applications. However, further studies are needed to determine the role of long-term pilot scale operation on the properties and performance of this filter.

Acknowledgments: This work was supported by Deanship of Scientific Research at Qaussim University (1868-qec-2016-1-12-S). Assistance from Engineer Abdullah Al-Ghonaim and Engineer Abdul Kareem for their cooperation in completion of water analysis and laboratory experiments are acknowledged gratefully.

Author Contributions: Md Shafiquzaman, Saleem S. AlSaleem, and Abdullah Al-Mahmud conceived and designed the experiments; Abdullah Al-Mahmud performed the experiments; Md Shafiquzzaman and Husnain Haidar analyzed the data; Md Shafiquzzaman and Abdullah Al-Mahmud wrote the paper.

Conflicts of Interest: We hereby declare no conflict of interest. 


\section{References}

1. Walsh, M.E.; Gagnon, G.A.; Alam, Z.; Andrews, R.C. Bio-stability and disinfectant by-product formation in drinking water blended with UF-treated filter backwash water. Water Res. 2008, 42, 2135-2145. [CrossRef] [PubMed]

2. Kim, Y.H.; Eom, J.Y.; Kim, K.Y.; Lee, Y.S.; Kim, H.S.; Hwang, S.J. Applicability study of backwash water treatment using tubular membrane system with dead-end filtration operation mode. Desalination 2010, 261, 104-110. [CrossRef]

3. Weiying, L.; Yuasa, A.; Bingzhi, D.; Naiyun, G. Study on backwash wastewater from rapid sand-filter by monolith ceramic membrane. Desalination 2010, 250, 712-715. [CrossRef]

4. Vigneswaran, S.; Boonthanonb, S.; Prasanthia, H. Filter backwash water recycling using crossflowmicrofiltration. Desalination 1996, 106, 31-38. [CrossRef]

5. Willemse, R.J.N.; Brekvoort, Y. Full-scale recycling of backwash water from sand filters using dead-end membrane filtration. Water Res. 1999, 33, 3379-3385. [CrossRef]

6. Li, S.; Heijman, S.G.J.; Verberk, J.Q.J.C.; Verliefde, A.R.D.; Kemperman, A.J.B.; VanDijk, J.C.; Amya, G. Impact of backwash water composition on ultrafiltration fouling control. J. Membr. Sci. 2009, 344, 17-25. [CrossRef]

7. Reissmann, F.G.; Uhl, W. Ultrafiltration for the reuse of spent filter backwash water from drinking water treatment. Desalination 2006, 198, 225-235. [CrossRef]

8. Ling, Z.L.; Dong, Y.; Zi-Jie, Z.; Ping, G. Application of hybrid coagulation-microfiltration process for treatment of membrane backwash water from water works. Sep. Purif. Technol. 2008, 62, 415-422.

9. Choi, K.Y.J.; Dempsey, B.A. In-line coagulation with low-pressure membrane filtration. Water Res. 2004, 38, 4271-4281. [CrossRef] [PubMed]

10. Howe, K.J.; Marwah, A.; Chiu, K.P.; Adham, S.S. Effect of coagulation on the Size of MF and UF membrane foulants. Environ. Sci. Technol. 2006, 40, 7908-7913. [CrossRef] [PubMed]

11. Chen, Y.; Dong, B.Z.; Gao, N.Y.; Fan, J.C. Effect of coagulation pretreatment on fouling of an ultra-filtration membrane. Desalination 2007, 204, 181-188. [CrossRef]

12. Liu, T.; Lian, Y.; Graham, N.; Yu, W.; Rooney, D.; Sun, K. Application of polyacrylamide flocculation with and without alum coagulation for mitigating ultrafiltration membrane fouling: Role of floc structure and bacterial activity. Chem. Eng. J. 2017, 307, 41-48. [CrossRef]

13. Moon, J.; Kang, M.S.; Lim, J.L.; Kim, C.H.; Park, H.D. Evaluation of a low-pressure membrane filtration for drinking water treatment: Pretreatment by coagulation/sedimentation for the MF membrane. Desalination 2009, 247, 271-284. [CrossRef]

14. Lee, J.D.; Lee, S.H.; Jo, M.H.; Park, P.K.; Lee, C.H.; Kwak, J.W. Effect of coagulation conditions on membrane filtration characteristics in coagulation-microfiltration process for water treatment. Environ. Sci. Technol. 2000, 34, 3780-3788. [CrossRef]

15. Wang, J.; Guan, J.; Santiwong, S.R.; Waite, T.D. Characterization of floc size and structure under different monomer and polymer coagulants on microfiltration membrane fouling. J. Membr. Sci. 2008, 321, $132-138$. [CrossRef]

16. Huang, C.; Lina, J.L.; Leea, W.S.; Panb, J.R.; Zhaoc, B. Effect of coagulation mechanism on membrane permeability in coagulation-assisted microfiltration for spent filter backwash water recycling. Colloids Surf. A Physicochem. Eng. Asp. 2011, 378, 72-78. [CrossRef]

17. Lin, J.L.; Huang, C.P.; Pan, J.R.; Wang, D.S. Effect of Al (III) speciation on coagulation of highly turbid water. Chemosphere 2008, 72, 189-196. [CrossRef] [PubMed]

18. Song, H.; Fan, X.; Zhang, Y.; Wang, T.; Feng, Y. Application of microfiltration for reuse of backwash water in a conventional water treatment plant-A case study. Water Supply 2001, 1, 199-206.

19. Nasser, A.; Huberman, Z.; Dean, L.; Bonner, F.; Adin, A. Coagulation as a pretreatment of SFBW for membrane filtration. Water Supply 2002, 2, 301-306.

20. Huang, C.P.; Lin, J.L.; Wu, C.L.; Chu, C.P. Recycling of spent filter backwash water using coagulation-assisted membrane filtration: Effects of submicron particles on membrane flux. Water Sci. Technol. 2010, 61, 1923-1929. [CrossRef] [PubMed]

21. Shafiquzzaman, M.; Hasan, M.M.; Nakajima, J.; Mishima, I. Development of a simple and effective arsenic removal filter based on ceramic filtration. J. Water Environ. Technol. 2011, 9, 333-347. [CrossRef] 
22. Hasan, M.M.; Shafiquzzaman, M.; Azam, M.S.; Nakajima, J. Application of a simple ceramic filter to membrane bioreactor. Desalination 2011, 276, 272-277. [CrossRef]

23. Hasan, M.M.; Shafiquzzaman, M.; Nakajima, J.; Ahmed, A.T.K.; Azam, M.S. Application of low cost ceramic filter to Membrane Bioreactor for grey water Treatment. Water Environ. Res. 2015, 87, 233-241. [PubMed]

24. Zheng, W.Y.; Nigel, G.; Hui-juan, L.; Jiu-hui, Q. Comparison of $\mathrm{FeCl}_{3}$ and alum pre-treatment on UF membrane fouling. Chem. Eng. J. 2013, 234, 158-165.

25. Hermia, J. Constant pressure blocking filtration laws-Application to power-law non-newtonian fluids. Trans. Inst. Chem. Eng. 1982, 60, 183-187.

26. Lim, A.L.; Bai, R. Membrane fouling and cleaning in microfiltration of activated sludge wastewater. J. Membr. Sci. 2003, 216, 279-290. [CrossRef]

27. Nandi, B.K.; Uppaluri, R.; Purkait, M.K. Treatment of Oily Waste Water Using Low-Cost Ceramic Membrane: Flux Decline Mechanism and Economic Feasibility. Sep. Sci. Technol. 2009, 44, 2840-2869. [CrossRef]

28. World Health Organization (WHO). WHO Guideline for Drinking Water Quality, 4th ed.; World Health Organization: Geneva, Switzerland, 2004.

(C) 2018 by the authors. Licensee MDPI, Basel, Switzerland. This article is an open access article distributed under the terms and conditions of the Creative Commons Attribution (CC BY) license (http:/ / creativecommons.org/licenses/by/4.0/). 